\title{
PENUTUPAN JALAN UMUM PADA SAAT \\ SHALAT JUM'AT BERLANGSUNG MENURUT \\ HUKUM/SYARIAT ISLAM
}

\author{
Muh. Yunan Putra \\ Institut Agama Islam (IAI) Muhammadiyah Bima \\ Jln. Anggrek No. 16 Ranggo Na'e Kota Bima \\ Email: mohammed.elgehady@gmail.com
}

\section{Abstrak}

Indonesia adalah negara dengan penduduk mayoritas Islam terbesar di dunia, maka tidak heran tempat ibadah seperti masjid dan mushalla tidak terbilang jumlahnya. Bahkan ada sebuah daerah/kota di Indonesia karena saking banyaknya tepat ibadah tersebut sampai dijuluki dengan kota seribu Masjid. Masjid yang menjadi simbol umat Islam pada hakikatnya tidak hanya digunakan untuk kegiatan shalat saja, lebih dari itu ada banyak kegiatan-kegiatan lain yang biasa dilakukan dan diadakan di Masjid, seperti musyawarah, nikah, pengajian dan lain sebagainya. Namun pada tulisan kali ini penulis tidak akan membahas semua kegiatan-kegiatan tersebut namun hanya akan mengkerucutkan pada sebuah permasalahan, yaitu kegiatan mingguan yang biasa disebut dengan jum'atan (ibadah shalat jum'at). Pada hakikatnya tidak ada permasalahan yang perlu dibahas pada ibadah shalat jum'at tersebut, namun ada peristiwa menarik yang baru beberapa tahun terakhir ditemukan dilapangan (hanya terjadi pada beberapa tempat dan beberapa Masjid); bahwa pada saat ibadah jum'at dilaksanakan, para pengurus Masjid menutup jalan-jalan disekitaran Masjid sehingga kendaraan harus 
mengambil jalur lain untuk melanjutkan perjalanan, bahkan sebagian Masjid menutup jalan-jalan tersebut jauh sebelum kegiatan atau ibadah shalat jum'at dilaksanakan, alasannya agar tidak mengganggu jama'ah yang sedang khusuk dalam beribadah terlebih penutupan jalan yang dimaksud dikuatkan oleh peraturan pemerintah sekitar. Berdasarkan tujuan dari tindakan tersebut sebenarnya tidak salah bahkan sangat baik, namun apabila melihat sisi negatif serta akibat yang ditimbulkan maka penulis sendiri menyimpulkan bahwa penutupan jalan tersebut kurang tepat. Hal ini didukung oleh beberapa dalil baik berupa nash maupun kaidah-kaidah ushuliyah yang telah ditetapkan oleh para ulama.

\section{Keywords: Jalan Umum, Shalat Jum'at, Hukum/Syariat Islam.}

\section{A. Pendahuluan}

Negara Indonesia adalah salah satu negara demokrasi dari sekian banyak negara yang ada di dunia, negara Indonesia adalah negara sekuler yang tidak memaksa penduduk dan masyarakatnya untuk memeluk satu agama saja, masyarakat diberikan kebebasan sepenuhnya untuk memilih satu dari enam agama yang telah ditetapkan, yaitu; Islam, Kristen, Katolik, Hindu, Budha dan konghucu. Kendatipun demikian sebagaimana yang dilansir oleh indonesia-investments.com, agama Islam menjadi agama mayoritas masyarakat Indonesia, yaitu dengan jumlah 87,2 porsen atau sekitar 207,2 juta dari jumlah penduduknya.

Oleh besarnya penduduk yang memeluk agama Islam, Indonesia terkadang dianggap sebagai negara Islam yang walaupun pada hakikatnya negara domokrasi. Oleh sebab itu pula tidak heran acara-acara keagamaan di Indonesia lebih didominasi oleh kegiatan-kegiatan masyarakat Islam, seperti 
Nuzul Qur'an, Isra' Mi'raj, Maulud Nabi SAW. dan lain sebagainya, termasuk kegiatan mingguan yang diangkat oleh penulis yaitu jum'atan (ibadah shalat jum'at).

Kegiatan shalat jum'at adalah kegiatan ibadah wajib ${ }^{1}$ yang setiap masjid di Indonesia dan dimanapun mengadakannya. Namun sebagian daerah yang penulis temukan bahwa ada beberapa masjid yang ketika jum'atan dilaksanakan bahkan sebelum ibadah jum'at ini dimulai, masjid-masjid tersebut menutup jalan umum yang berada diseputaran masjid. Mengakibatkan jalan lumpuh dan sebagian pengendara harus mengambil rute lain untuk meneruskan safar/perjalanan. Jelas ini mengganggu para pengguna jalan, terlebih para pengguna jalan tidak hanya orang Islam atau orang sekitar, bisa saja pengguna jalan tersebut adalah penganut agama lain atau mungkin orang asing yang sedang mengadakan safar/perjalanan jauh atau mungkin orang yang dalam keadaan darurat sehingga dengan adanya penutupan jalan tersebut jelas-jelas menghalangi.

Lalu bagaimana sebenarnya pandangan hukum Islam terkait hal tersebut, adakah dengan tujuan yang baik mengorbankan hak orang lain terlebih pengguna jalan tidak hanya warga sekitar atau tidak hanya orang Islam saja? Maka inilah yang hendak penulis bahas dalam tulisan singkat kali ini, dengan harapan memberikan masukan dan sedikit pengetahuan setidaknya untuk penulis sendiri.

${ }^{1}$ Lihat Al Qur'an Surat Al Jum'ah atat 9,: “Hai orang-orang beriman, apabila diseru untuk menunaikan shalat Jum'at, maka bersegeralah kamu kepada mengingat Allah dan tinggalkanlah jual beli. Yang demikian itu lebih baik bagimu jika kamu mengetahui." Khadīm al-Haramain al-Syarifain, Al-Qur'an dan Terjemahan Maknanya (Komplek Percetakan Al-Qur'an Al-Karim Raja Fahd, T.th), Hlm. 933. 


\section{B. Pengertian}

\section{Jalan Umum}

Secara umum, jalan adalah prasarana transportasi darat yang meliputi segala bagian jalan, termasuk bangunan pelengkap dan perlengkapannya yang diperuntukkan bagi lalu lintas, yang berada pada permukaan tanah, di atas permukaan tanah, di bawah permukaan tanah dan/atau air, serta di atas permukaan air, kecuali jalan kereta api, jalan lori, dan jalan kabel. ${ }^{2}$ Sedangkan menurut Undang-Undang Republik Indonesia Nomor 22 Tahun 2009, Jalan adalah seluruh bagian Jalan, termasuk bangunan pelengkap dan perlengkapannya yang diperuntukkan bagi Lalu Lintas umum, yang berada pada permukaan tanah, di atas permukaan tanah, di bawah permukaan tanah dan/atau air, serta di atas permukaan air, kecuali jalan rel dan jalan kabel. $^{3}$

Sedangkan pembagian jalan secara umumnya menurut undang-undang jalan terbagi menjadi dua ${ }^{4}$, jalan umum dan khusus. Yang dimaksud jalan umum adalah jalan yang diperuntukkan bagi lalu lintas umum; sedangkan jalan khusus adalah jalan yang dibangun oleh instansi, badan usaha, perseorangan, atau kelompok masyarakat untuk kepentingan sendiri. ${ }^{5}$ Dalam Kamus Besar Bahasa Indonesia

2 Lihat: Undang-Undang Republik Indonesia Nomor 38 Tahun 2004 Tentang Jalan Bab I Ketentuan Umum Pasal 1 point 4.

${ }^{3}$ Lihat: Undang-Undang Republik Indonesia Nomor 22 Tahun 2009 Tentang Lalu Lintas dan Angkutan Jalan Bab I Ketentuan Umum Pasal 1 Point 12.

${ }_{4}^{4}$ Lihat: Undang-Undang Republik Indonesia Nomor 38 Tahun 2004 Tentang Jalan Bab III Peran, Pengelompokan, dan Bagian-Bagian Jalan Bagian Pertama Peran Jalan Pasal 6 point 1.

${ }^{5}$ Opcit. Point 5 dan 6.

Sangaji Jurnal Pemikiran Syariah dan Hukum 
(KBBI) online jalan umum adalah jalan untuk umum (orang, kendaraan). ${ }^{6}$

Berdasarkan tujuannya menunrut undang-undang jalan nomor 38 tahun 2004 ini, ${ }^{7}$ pengaturan penyelenggaraan jalan bertujuan untuk:

a) Mewujudkan ketertiban dan kepastian hukum dalam penyelenggaraan jalan

b) Mewujudkan peran masyarakat dalam penyelenggaraan jalan;

c) Mewujudkan peran penyelenggara jalan secara optimal dalam pemberian layanan kepada masyarakat;

d) Mewujudkan pelayanan jalan yang andal dan prima serta berpihak pada kepentingan masyarakat;

e) Mewujudkan sistem jaringan jalan yang berdaya guna dan berhasil guna untuk mendukung terselenggaranya sistem transportasi yang terpadu; dan

f) Mewujudkan pengusahaan jalan tol yang transparan dan terbuka

\section{Shalat Jum'at}

Ibadah shalat jum'at adalah ibadah yang dilakukan oleh orang Islam dan menjadi wajib hukumnya bagi yang telah cukup syarat dan ketentuannya. Menurut Mulkhan Abdul Munir, ${ }^{8}$ shalat jum'at adalah shalat yang dikerjakan secara berjamaah tempatnya di Masjid atau yang difungsikan sebagai Masjid di mana salah seorang bertindak

${ }^{6}$ Lihat: https://kbbi.web.id/jalan

7 Lihat: Undang-Undang Republik Indonesia Nomor 38 Tahun 2004 Tentang Jalan Bab II Asas, Tujuan dan Lingkup, pasal 3.

8 Mulkhan Abdul Munir. 2005. Masalah-Masalah Teologi dan Figh dalam Tarjih Muhammadiyah. Yogyakarta: Roykhan. Hal. 346. 
sebagai imam dan lainnya sebagi makmum. Shalat Jum'at di dahului oleh khutbah Jum'at dan merupakan pengganti shalat dhuhur.

Menurut Syaikh Wahbah Al Zuhaili, ${ }^{9}$ Diberi nama dengan Jum'at karena berkumpulnya orang-orang pada hari tersebut, berkumpulnya kebaikan pada hari tersebut. Atau, karena penciptaan nabi Adam AS terhimpun di hari tersebut atau karena berkumpulnya Adam dan Hawa di bumi pada hari tersebut. Adapun nama lama untuk hari Jum'at pada zaman Jahiliyah dulu adalah hari Arubah, yaitu jelas besar, dikatakan hari al Rahmah.

Sedangkan menurut H. Sulaiman Rasjid ${ }^{10}$ Shalat Jum'at adalah Shalat dua rakaat sesudah khutbah pada waktu dhuhur pada hari Jum'at. Shalat Jum'at itu fardhu ain, Artinya wajib atas tiap-tiap laki-laki yang dewasa dan beragama Islam, merdeka, dan tetap di dalam negeri. Tidak wajib Jum'at atas perempuan, kanak-kanak, hamba sahaya, dan orang yang sedang dalam perjalanan.

Dapat disimpulkan bahwa pengertian shalat jum'at adalah shalat dua rakaat yang dilakukan oleh orang Islam pada hari jum'at dan menjadi menjadi wajib bagi yang telah memenuhi syarat dan ketentuan dan sunnah bagi wanita dan anak-anak.

\section{Pembahasan}

\section{a) Pendahuluan}

Hukum Islam atau yang biasa disebut syariat Islam adalah sebuah sebuah hukum yang datang langsung dari Allah SWT. Berbedadengan hukum yang dibuat oleh tangan

9 Wahbah Az-Zuhaili. 2010. Figh Islam 2. Jakarta: Gema Insani. Hal. 374.

${ }_{10}$ H. Sulaiman Rasjid dan kawan-kawan. 1992. Figh Islam. Bandung: CV. Sinar Baru. Hal. 124.

Sangaji Jurnal Pemikiran Syariah dan Hukum 
manusia, syariat Islam adalah hukum yang benar-benar sempurna yang tidak lagi membutuhkan akal pikiran manusia untuk menggeser apalagi sampai mengubahnya. Syariat Islam pada hakikatnya dibuat dengan tujuan kemaslahatan manusia dalam menjalani kehidupan di dunia terlebih di akhirat kelak. Hukuman-hukuman yang telah ditetapkan Allah didalamnya terkait tindak pidana adalah bersifat mutlak dengan tujuan memberikan dampak dan efek jera terhadap para pelaku dan juga kepada orang-orang yang melihat prosesi pelaksanaan hukuman terhadap tindakan pidana. Maka tidak heran disebagian ayat memerintahkan dalam pelaksanaan hukuman sengaja diperintahkan untuk melakukannya di hadapan halayak ramai, salah satunya misal:

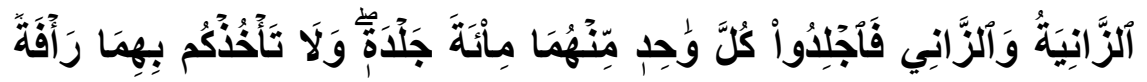

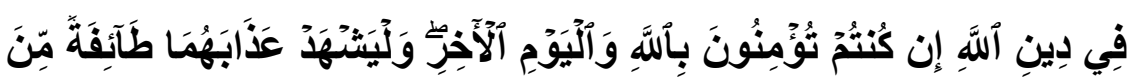

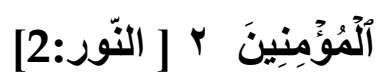

Terjemahnya:

"Perempuan yang berzina dan laki-laki yang berzina, maka deralah tiap-tiap seorang dari keduanya seratus dali dera, dan janganlah belas kasihan kepada keduanya mencegah kamu untuk (menjalankan) agama Allah, jika kamu beriman kepada Allah, dan hari akhirat, dan hendaklah (pelaksanaan) hukuman mereka disaksikan oleh sekumpulan orang-orang yang beriman." [QS. An Nur: 2] $]^{11}$

Ada beberapa negara Islam saat ini masih menerapkan hukum atau syariat Islam, misalnya Arab Saudi, Qatar, Irak Yaman dan Brunai Darussalam. Di Indonesia sendiri juga

11 Khadīm al-Haramain al-Syarifain, Al-Qur'an dan Terjemahan Maknanya (Komplek Percetakan Al-Qur'an Al-Karim Raja Fahd, T.th), Hlm. 543. 
telah ada salah satu propinsi yang yang menerapkan syariat Islam walaupun belum sepenuhnya, yaitu Nangro Aceh Darussalam. Dampak positif yang diperoleh dari penerapan syariat Islam pada daerah-daerah tersebut adalah berkurangnya tindakan pidana secara segnifikan termasuk makmurnya kehidupan dalam bermasyarakat dan bernegara. Hal ini memang telah dijanjikan oleh Allah SWT dalam firman-Nya:

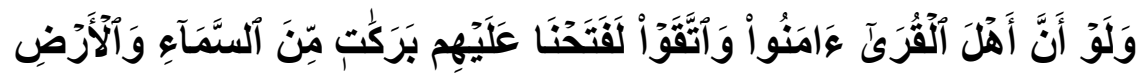

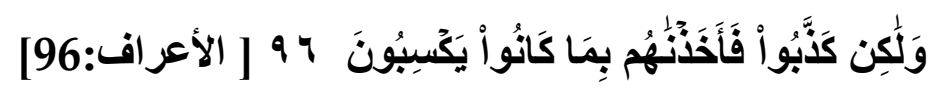

Terjemahnya:

"Jikalau sekiranya penduduk negeri-negeri beriman dan bertakwa, pastilah Kami akan melimpahkan kepada mereka berkah dari langit dan bumi, tetapi mereka mendustakan (ayat-ayat Kami) itu, maka Kami siksa mereka disebabkan perbuatannya." [QS. Al A'raf: 96] ${ }^{12}$

Dasar utama kenapa di Negara Indonesia khususnya, tidak dapat menerapkan syariat Islam tidak lain karena negara Indonesia adalah negara dengan bentuk pemerintahan demokrasi, sehingga hukum berdiri diatas Undang-Undang dan Pancasila. Selain itu, penduduk negara Indonesia terdiri dari berbagai macam golongan, ras, suku serta agama yang berbeda-beda. Walaupun demikian ditemukan beberapa hukum yang hampir seratus porsennya menggunakan hukum Islam/Syariat Islam, seperti hukum waris, wasiat, hibah dan wakaf. Beberapa buku yang dapat dijadikan pedoman misalnya; Hukum Islam dalam Hukum Positif Indonesia karangan Dr. Mardani atau Hukum Positif Indonesia karya Prof. Dr. Bagir Manan, SH., M.C.I.

${ }_{12}$ Ibid, Hlm. 237.

Sangaji Jurnal Pemikiran Syariah dan Hukum 
Sebagaimana dijelaskan sebelumnya bahwa Indonesia adalah negara dengan penduduk mayaoritas Islam, maka tidak heran kegiatan-kegiatan ibadah selalu ditemukan diberbagai tempat, daerah dan pada umumnya kegiatan tersebut diadakan di masjid-masjid terdekat, sebagian bersikap legowo, tidak mempermasalahkan ketika orang sekitar atau para pejalan melintas atau sekedar lewat dengan kendaraan. Namun tidak jarang dibeberapa daerah merasa tidak nyaman bahkan merasa terganggu kekhusu'an mereka dalam beribadah, terkhusus kegiatan tersebut adalah kegiatan ibadah wajib yang benar-benar membutuhkan ketenangan dalam beribadah, seperti ibadah shalat jum'at.

Berangkat dari kegelisahan tersebut, serta perhatian dari pemerintah daerah, maka dikeluarkanlah beberapa peraturan yang membolehkan penutupan jalan/pemblokiran jalan pada saat-saat tertentu ketika ibadah tengah dilaksanakan, khususnya ibadah shalat jum'at. Penulis merasa tertarik untuk menjelaskan ini, karena bertemunya dua pokok permasalahan penting yang keduanya memiliki tujuan yang baik dan mulia, yaitu; pertama, penutupan jalan dengan tujuan menjaga kekhusu'an dalam beribadah dan kedua, tidak menutup jalan dengan tujuan kemaslahatan bagi para penjalan, musafir dan orang-orang yang dalam keadaan darurat terlebih sebagaimana dijelaskan oleh undang-undang bahwa jalan sebagai hak setiap orang menggunakannya.

\section{b) Penutupan Jalan Saat Ibadah berlangsung}

Pada hakikatnya, tidak ditemukan dalam Al Qur'an tentang pelarangan menutup jalan terlebih hal tersebut datang dengan tujuan yang baik, yaitu menjaga kekhusu'an para jama'ah yang tengah beribadah. Adapun dalam hadits, 
larangan tersebut bersyarat yaitu tetap menjaga hak-hak pengguna jalan. Hal ini sebagaimana hadits riwayat Muslim yang menceritakan tentang beberapa orang sahabat yang duduk di jalan.

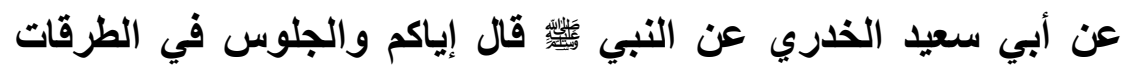
قالوا يا رسول الله ما لنا بـ من مجالسنا نتحدث فيها قال رسول الله صلى الى الله عليه وسلم فإذا أبيتم إلا المجلس فأعطوا الطريق حقه قالوا وما حقه قال غض البصر وكف الأذى ورد السلام والأمر بالمعروف والنهي عن المنكر

Artinya:

Dari Abu Sa'id Al Khudri dari Nabi SAW beliau bersabda: "Hindarilah olehmu duduk-duduk di pinggir jalan!" Para sahabat bertanya: "Ya Rasulullah bagaimana kalau kami butuh untuk duduk-duduk di situ memperbincangkan hal yang memang perlu?." Rasulullah SAW menjawab: "Jika memang perlu kalian duduk-duduk di situ, berikanlah hak jalanan." Mereka bertanya: "Apa haknya ya Rasulullah?" beliau menjawab: "Tundukkan pandangan, jangan mengganggu, menjawab salam (orang lewat), menganjurkan kebaikan, dan mencegah yang mungkar." (HR. Muslim)

Illat atau sebab larangan tersebut dalam hadits di atas adalah ditakutkan oleh Rasulullah mengganggu pengguna jalan dan menjadi majelis ghibah (membicarakan keburukan orang) serta tidak memiliki tujuan yang jelas. Adapun apabila memiliki tujuan yang baik dan jelas, maka bolehboleh saja.

Demikian halnya jika dikembalikan pada kaidah ushul fikh yang mengungkapkan bahwa:

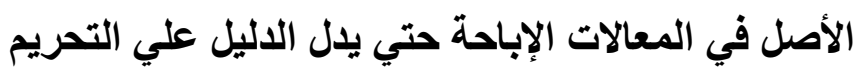

Sangaji Jurnal Pemikiran Syariah dan Hukum 
Artinya:

"Hukum asli dari bermu'amalah adalah dibolehkan hingga ditemukan dalil yang mengharamkannya."13

Dilihat dari beberapa manfaat dan kebaikan dari menutupi jalan pada saat ibadah jum'at sedang berlangsung diantaranya:

1) Terjaganya kekhusu'an beribadah para jama'ah shalat jum'at.

2) Tujuan yang baik dan mulia untuk menghormati dan menghargai para jama'ah yang sedang beribadah.

3) Memahami pentingnya ibadah dan mendekatkan diri kepaada Allah SWT.

4) Bahwa untuk mencapai kekhusu'an dalam beribadah membutuhkan pengorbanan.

5) Timbulnya rasa peka tehadap sesama masyarakat dan agama untuk saling menghormati terkhusus ketika sedang beribadah.

6) Belajar menghargai dan menghormati keputusan pemerintah daerah sebagai ulil amri yang memegang kekuasaan dan pengambil keputusan.

\section{c) Kaidah Ushul Fikh}

Pada dasarnya keputusan sebagian masyarakat dan pemerintah daerah tersebut diatas adalah sebuah tindakan yang baik dan mendatangkan manfaat, terlebih datang dengan tujuan yang mulia, yaitu menghormati orang yang sedang beribadah dan sebagai salah satu upaya meraih kekhusu'an. Namun jika dilihat dari sudut padang yang

${ }^{13}$ Duski Ibrahim. 2019. Al-Qawa Id Al-Fiqhiyah (Kaidah-Kaidah Fiqih), Cet. I. Palembang: CV. Amanah. Hlm. 61. 
berbeda, maka bisa juga dilihat beberapa kekurangan yang mengakibatkan ketidaknyamanan bagi sebagian orang sebagai pengguna jalan.

Maka disinilah letak kontrofersi dalam pengambilan keputusan tersebut dengan beberapa pertimbangan:

a) Tidak semua pengguna jalan adalah masyarakat sekitar saja, tapi juga masyarakat dari daerah lain terlebih jalan tersebut adalah jalan umum.

b) Tidak semua pula masyarakat menetap (muqim) pada saat hari jum'at, diantaranya ada yang musafir keluar daerah karena keperluan yang mendadak atau yang lainnya.

c) Tidak semua masyarakat dalam keadaan sehat sehingga bisa selalu beribadah dengan baik di masjid, tapi juga sebagian dalam keadaan darurat dan butuh cepat untuk dilarikan ke rumah sakit.

d) Tidak semua masyarakat beragama Islam tapi juga sebagian dari mereka beragama Non-Islam yang mungkin tidak rela perjalanannya terganggu oleh penutupan jalan umum tersebut.

Artinya disini terdapat dua mudharat yang sama-sama akan ditimbulkan ketika jalan dibuka ataupun ditutup, mudharat ketika dibuka yaitu kekhusu'an orang yang sedang beribadah akan terganggu dan mudharatnya apabila dibuka yaitu menggangu para pemakai jalan. Dalam sebuah kaidah ushul fikh menyebutkan:

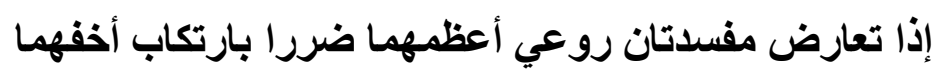

Sangaji Jurnal Pemikiran Syariah dan Hukum 
Artinya:

"Apabila ada dua kerusakan berlawanan, maka haruslah dipelihara yang lebih berat mudharatnya dengan melakukan yang lebih ringan dari keduanya." 14

Maka dari dua permasalahan diatas perlu kiranya dilihat dan ditinjau kembali, manakah dari kedua permasalahan tersebut yang lebih besar kerusakan yang ditimbulkan. Sama halnya ketika seorang wanita meninggal dalam keadaan hamil tua atau dalam perutnya terdapat seorang bayi yang sudah siap untuk dilahirkan. Rasulullah SAW melarang bersikap kasar terhadap seorang mayat ${ }^{15}$ terbih menyakitinya dengan membelah perutnya, namun ada mudharat yang lebih besar ditimbulkan apabila perut wanita tersebut tidak dibelah, anak yang ada dalam kandungannya akan mati. Maka disini mudharat yang lebih ringan dipilih untuk kebaikan yaitu membelah perut si mayit demi menyelamatkan si bayi.

Kaidah lainnya adalah:

Artinya:

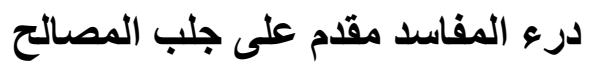

"Menolak kerusakan harus didahulukan dari pada mendatangkan kemaslahatan."16

Dari kaidah ini dipahami bahwa manakala terjadi pertentangan antara kemudharatan dan kemaslahatan, maka segi kemudharatannya (kerusakannya atau larangannya) harus didahulukan untuk dihindari. Seperti

14 Duski Ibrahim. 2019. Al-Qawa Id Al-Fiqhiyah (Kaidah-Kaidah Fiqih), Cet. I. Palembang: CV. Amanah. Hlm. 85.

${ }^{15}$ Lihat: hadits riwayat Aisyah: dari Aisyah bahwa Rasulullah shallallahu 'alaihi wa sallam berkata: "Mematahkan tulang orang yang mati seperti halnya mematahkannya ketika ia masih hidup." (HR. Abu Daud, Ibnu Majah dan Ahmad)

16 Duski Ibrahim. 2019. Al-Qawa Id Al-Fiqhiyah (Kaidah-Kaidah Fiqih), Cet. I. Palembang: CV. Amanah. Hlm. 84. 
misalnya berkumur-kumur (madhmadhah) ketika sedang berpuasa. Satu sisi mengandung kemaslahatan untuk membersihkan mulut, tetapi di sisi lain mengandung kerusakan yaitu membahayakan atau membatalkan ibadah puasa. Maka berdasarkan kaidah ini, yang yang terbaik untuk dilakukan adalah tidak berkumur-kumur, untuk menghindari batalnya puasa.

\section{d) Undang-Undang dan PP Tentang Jalan Umum}

Selain dua kaidah yang telah disebutkan sebelumnya, berikut beberapa kutipan Undang-Undang dan Peraturan Pemerintah terkait Jalan yang menjadi hak masyarakat. (penulis tidak memasukkan semua UU dan PP terkait Jalan ini, hanya mengangkat beberapa yang di anggap perlu sesuai pembahasan)

\section{1) Undang-Undang Republik Indonesia Nomor 38 Tahun 2004 Tentang Jalan ${ }^{17}$}

\section{BAB I \\ KETENTUAN UMUM \\ Pasal 1}

Point 4. Jalan adalah prasarana transportasi darat yang meliputi segala bagian jalan, termasuk bangunan pelengkap dan perlengkapannya yang diperuntukkan bagi lalu lintas, yang berada pada permukaan tanah, di atas permukaan tanah, di bawah permukaan tanah dan/atau air, serta di atas permukaan air, kecuali jalan kereta api, jalan lori, dan jalan kabel;

Point 5. Jalan umum adalah jalan yang diperuntukkan bagi lalu lintas umum;

${ }^{17}$ Lihat: http://bit.ly/39COi91

Sangaji Jurnal Pemikiran Syariah dan Hukum 


\section{BAB II \\ ASAS, TUJUAN, DAN LINGKUP \\ Pasal 2}

Penyelenggaraan jalan berdasarkan pada asas kemanfaatan, keamanan dan keselamatan, keserasian, keselarasan dan keseimbangan, keadilan, transparansi dan akuntabilitas, keberdayagunaan dan keberhasilgunaan, serta kebersamaan dan kemitraan.

\section{Pasal 3}

Pengaturan penyelenggaraan jalan bertujuan untuk:

a. Mewujudkan ketertiban dan kepastian hukum dalam penyelenggaraan jalan;

b. Mewujudkan peran masyarakat dalam penyelenggaraan jalan;

c. Mewujudkan peran penyelenggara jalan secara optimal dalam pemberian layanan kepada masyarakat;

d. Mewujudkan pelayanan jalan yang andal dan prima serta berpihak pada kepentingan masyarakat;

e. Mewujudkan sistem jaringan jalan yang berdaya guna dan berhasil guna untuk mendukung terselenggaranya sistem transportasi yang terpadu; dan

f. Mewujudkan pengusahaan jalan tol yang transparan dan terbuka.

2) Peraturan Pemerintah Republik Indonesia Nomor 34 Tahun 2006 Tentang Jalan ${ }^{18}$

\section{BAB I \\ KETENTUAN UMUM \\ Pasal 1}

Dalam Peraturan Pemerintah ini yang dimaksud dengan:

${ }^{18}$ Lihat: http://bit.ly/31H4GBg 
Point 3. Jalan adalah prasarana transportasi darat yang meliputi segala bagian jalan, termasuk bangunan pelengkap dan perlengkapannya yang diperuntukkan bagi lalu lintas, yang berada pada permukaan tanah, di atas permukaan tanah, di bawah permukaan tanah dan/atau air, serta di atas permukaan air, kecuali jalan kereta api, jalan lori, dan jalan kabel.

Point 4. Jalan umum adalah jalan yang diperuntukkan bagi lalu lintas umum.

\section{BAB II \\ JALAN UMUM \\ Pasal 3}

Point (1) Penyelenggaraan jalan umum dilakukan dengan mengutamakan pembangunan jaringan jalan di pusatpusat produksi serta jalan-jalan yang menghubungkan pusat-pusat produksi dengan daerah pemasaran.

Point (2) Penyelenggaraan jalan umum diarahkan untuk pembangunan jaringan jalan dalam rangka memperkokoh kesatuan wilayah nasional sehingga menjangkau daerah terpencil.

Point (3) Penyelenggaraan jalan umum diarahkan untuk mewujudkan:

- Perikehidupan rakyat yang serasi dengan tingkat kemajuan yang sama, merata, dan seimbang; dan

- Daya guna dan hasil guna upaya pertahanan keamanan negara.

\section{Pasal 4}

Point (1) Penyelenggara jalan umum wajib mengusahakan agar jalan dapat digunakan sebesar-besar kemakmuran rakyat, terutama untuk meningkatkan pertumbuhan ekonomi nasional, dengan mengusahakan agar biaya umum perjalanan menjadi serendah-rendahnya.

Point (2) Penyelenggara jalan umum wajib mendorong ke arah terwujudnya keseimbangan antardaerah, dalam hal 
pertumbuhannya mempertimbangkan satuan wilayah pengembangan dan orientasi geografis pemasaran sesuai dengan struktur pengembangan wilayah tingkat nasional yang dituju.

Point (3) Penyelenggara jalan umum wajib mendukung pertumbuhan ekonomi di wilayah yang sudah berkembang agar pertumbuhannya tidak terhambat oleh kurang memadainya prasarana transportasi jalan, yang disusun dengan mempertimbangkan pelayanan kegiatan perkotaan.

Point (4) Dalam usaha mewujudkan pelayanan jasa distribusi yang seimbang, penyelenggara jalan umum wajib memperhatikan bahwa jalan merupakan satu kesatuan sistem jaringan jalan.

\section{e) Akibat ditutupnya Jalan}

Berikut beberapa akibat yang terjadi ketika ditutupnya akses jalan, walaupun dengan alasan menjaga kekhusu'an dalam beribadah:

a) Para pengguna jalan sulit menemukan jalan lain karena tidak semua dari mereka adalah penduduk setempat.

b) Membuka peluang timbulnya prasangka buruk dari nonmuslim yang tidak paham tentang maksud dari penutupan jalan tersebut.

c) Terhalangnya jalan bagi para musafir, terkhusus mereka yang terburu-buru atau dalam keadaan darurat ingin sampai ke tujuan.

d) Menimbulkan ketidaknyamanan sebagian masyarakat yang berakhir dengan konflik.

\section{Analisis dan Simpulan}

Berdasarkan uraian diatas; penutupan jalan pada saat beribadah terkhusus pada saat ibadah shalat jum'at adalah sesuatu yang memang dibutuhkan demi terciptanya sebuah ibadah yang khusu' dan berkualitas. Terlebih hal tersebut 
memberikan beberapa manfaat lain seperti tercapainya tujuan yang baik dan mulia untuk menghormati dan menghargai para jama'ah yang sedang beribadah, memberikan pemahaman pentingnya ibadah dan mendekatkan diri kepaada Allah SWT., bahwa untuk mencapai kekhusu'an dalam beribadah membutuhkan pengorbanan, timbulnya rasa peka tehadap sesama masyarakat dan agama untuk saling menghormati terkhusus ketika sedang beribadah, serta belajar menghargai dan menghormati keputusan pemerintah daerah sebagai ulil amri yang memegang kekuasaan dan pengambil keputusan.

Namun satu hal yang juga perlu diperhatikan adalah bahwa keputusan tersebut hendaknya melihat kembali dampak negatif yang ditimbulkan olehnya. Menurut hemat penulis, dampak tersebut masuk kategori dampak yang cukup menimbulkan ketidaknyamanan terhadap para pengguna jalan, terlebih non-muslim. Hal lain yang ditimbulkan adalah para pengguna jalan sulit menemukan jalan lain karena tidak semua dari mereka adalah penduduk setempat, terhalangnya jalan bagi para musafir terkhusus mereka yang terburu-buru atau dalam keadaan darurat ingin sampai ke tujuan, serta menimbulkan ketidaknyamanan sebagian masyarakat yang berakhir dengan konflik.

Hal ini belum lagi bertentangan dengan Undang-Undang dan Peraturan Pemerintah, sehingga penutupan jalan ini secara mu'amalah (hubungan sosial masyarakat) maupun negara yang berdasar kepada Undang-Undang dan Pancasila melanggar. Maka apabila dikombinasikan dua permasalahan tersebut diatas, maka akan kembali kepada kaidah;

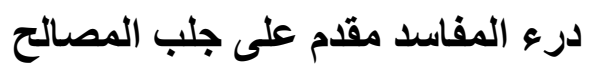

Sangaji Jurnal Pemikiran Syariah dan Hukum 
Artinya:

"Menolak kerusakan harus didahulukan dari pada mendatangkan kemaslahatan."19 Wallahu a'lam bisshawab...

${ }^{19}$ Duski Ibrahim. 2019. Al-Qawa Id Al-Fiqhiyah (Kaidah-Kaidah Fiqih), Cet. I. Palembang: CV. Amanah. Hlm. 84. 


\section{Daftar Pustaka}

Al-Syarifain Khadīm al-Haramain, Al-Qur'an dan Terjemahan Maknanya (Komplek Percetakan Al-Qur'an Al-Karim Raja Fahd, T.th), Hlm. 933.

Undang-Undang Republik Indonesia Nomor 38 Tahun 2004 Tentang Jalan

Undang-Undang Republik Indonesia Nomor 22 Tahun 2009 Tentang Lalu Lintas dan Angkutan Jalan

Munir Mulkhan Abdul. 2005. Masalah-Masalah Teologi dan Figh dalam Tarjih Muhammadiyah. Yogyakarta: Roykhan.

Az-Zuhaili Wahbah. 2010. Figh Islam 2. Jakarta: Gema Insani.

Rasjid H. Sulaiman dan kawan-kawan. 1992. Fiqh Islam. Bandung: CV. Sinar Baru.

Ibrahim Duski. 2019. Al-Qawa'Id Al-Fiqhiyah (Kaidah-Kaidah Fiqih), Cet. I. Palembang: CV. Amanah.

http://bit.ly/31H4GBg

https://kbbi.web.id

http://bit.ly/39COi91

Sangaji Jurnal Pemikiran Syariah dan Hukum 